\title{
Ground Water Vis-A-Vis Sea Water Intrusion Analysis for a Part of Limestone Tract of Gujarat Coast, India
}

\author{
Abhay K. Soni ${ }^{1, *}$, Paras R. Pujari ${ }^{2}$ \\ ${ }^{1}$ Central Institute of Mining and Fuel Research, Nagpur, India \\ ${ }^{2}$ National Environmental Engineering Research Institute, Nagpur, India \\ E-mail:abhayksoni@gmail.com,aksjournal@yahoo.co.in \\ Received June 20, 2009; revised December 10, 2009; accepted February 10, 2010
}

\begin{abstract}
The present study analyses the hydro-chemical data of groundwater samples of three different limestone mine sites, which are in close proximity and covers a tract along the Gujarat Coast of Indian peninsula. Higher TDS ( $>4000 \mathrm{mg} / \mathrm{L})$ and $\mathrm{Cl}$ values $(>2000 \mathrm{mg} / \mathrm{L})$ as well as the Chloride: Bicarbonate $\left(\mathrm{HCO}_{3}\right)$ ratio of more than one clearly support that the sea water intrusion is present in the coastal aquifer at all the three sites. In view of the economic importance of the area and the vulnerability of the coastal aquifer to sea water intrusion recommendations are made for sustainable use of groundwater by the mining companies and other stake holders.
\end{abstract}

Keywords: Coastal Aquifer, Seawater Intrusion, TDS, Limestone

\section{Introduction}

The Gujarat state of Indian Peninsula is bounded by latitudes N $20^{\circ} 02^{\prime}$ and $\mathrm{N} 24^{\circ} 42^{\prime}$ and longitudes E $68^{\circ} 04^{\prime}$ and $\mathrm{E} 74^{\circ} 30^{\prime}$ and has an areal extent of $196,024 \mathrm{~km}^{2}$ (Figure 1). The western and southern parts of the state are bounded by the costal tract along the Arabian Sea. The state of Gujarat has a long coastline of approximately $1550 \mathrm{~km}$ extending in the Kuchch Peninsula, the Saurashtra Peninsula and the Central Plains of Gujarat. The Kuchch Peninsula and Rann of Kuchch adjacent to the district of Jamnagar, Junagarh, Amreli and Bhavnagar occupy the N-W part of Gujarat Coast line and is also termed as Saurashtra Coast. The coast is abundantly rich in commercial variety of limestone (Table 1).

It is used as raw material for manufacture of lime, cement fertilizers and chemicals like soda-ash, bleaching powder, calcium carbide etc. It is also used as flux in iron and steel industries, ferro-alloys and other metallurgical industries.

The limestone is commercially exploited by open cast mining in the coastal tract. Hence, it is desirable that the local hydro-geological regime and hydrochemical studies need to be considered in mining strategy for the exploitation of limestone. Considering this fact, scientific studies have been undertaken separately by the mining companies to decipher the sea water intrusion and plan the use of groundwater in a sustainable manner accordingly. The present study seeks to integrate the findings from studies [1-3] conducted at three different sites in the Saurashtra coast. The objective is to examine the existing data and decipher the signature of sea water intrusion in the coastal aquifer at the mining sites.

\section{Study Area}

The present study analyses the groundwater hydrochemistry from three different locations in the Gujarat coast (Figure 1). The locations are as follow:

Site 1: Kovaya Limestone Mine Area of Gujarat Cement Works (GCW) in Amreli district, Gujarat.

Site 2: Jafrabad Limestone Mine Area of Narmada Cement Company Limited (NCCL) in Amreli district, Gujarat.

Site 3: Lodhwa/Singsar Limestone Area of Gujarat Ambuja Cement Limited (GACL) in Junagarh district, Gujarat.

Three different limestone mine sites lie on a stretch covering a tract along the Gujarat Coast of Indian peninsula. They are located in proximity of one another and can be considered as representative of the identical geological formations for study purpose. 


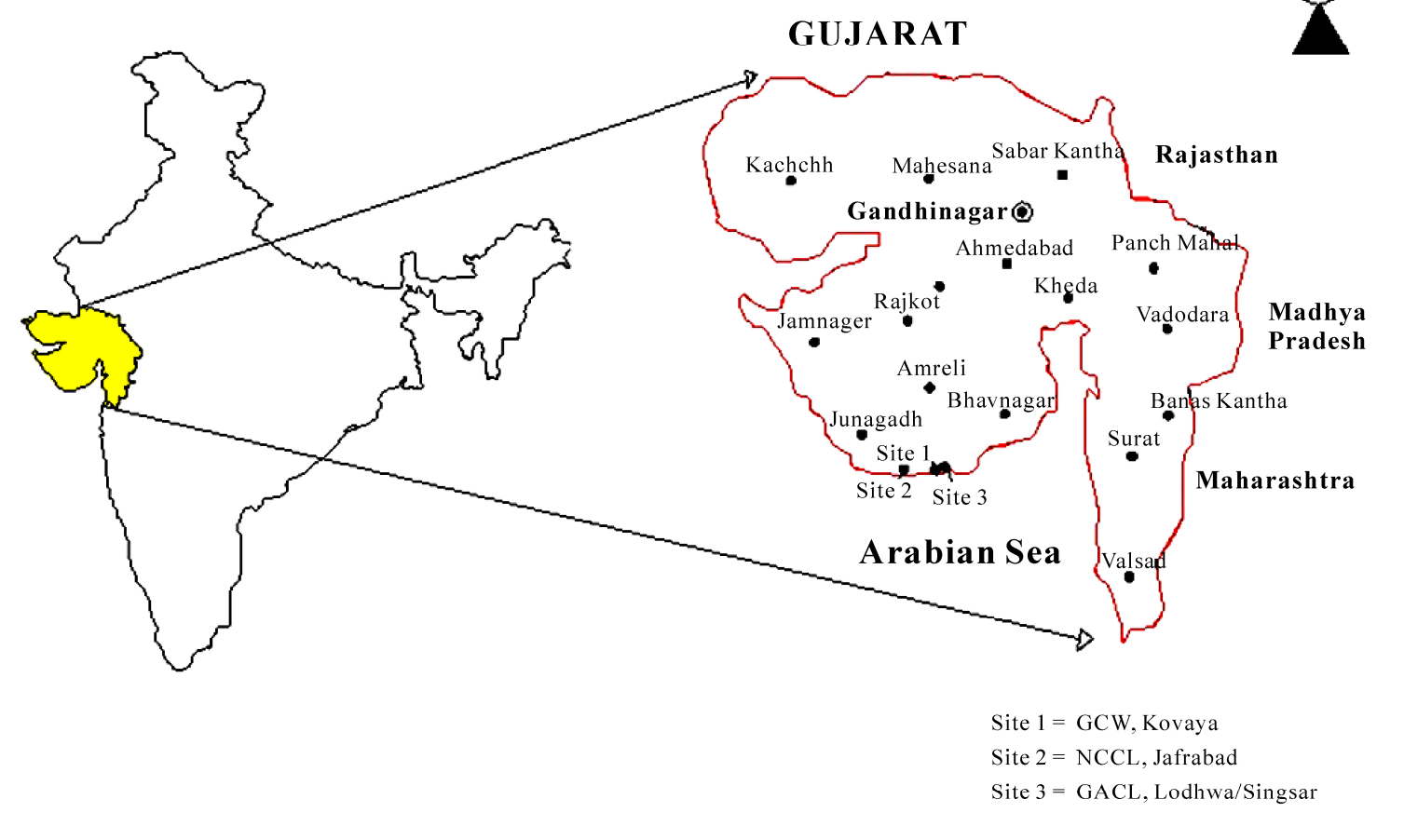

Figure 1. Location map of study area.

Table 1. Localities, geological age and formation types for limestone tract of gujarat coast, India.

\begin{tabular}{|c|c|c|c|c|}
\hline $\begin{array}{l}\text { S. } \\
\text { No. }\end{array}$ & $\begin{array}{l}\text { Name of } \\
\text { District }\end{array}$ & Localities & Geological Age/Era & Formation Type \\
\hline 1. & Amreli & $\begin{array}{l}\text { Balanivav, Una, Jafrabad, Kodinar, Mitiala, } \\
\text { Varaswarup, Chanch bet, Dantardi, Vandha }\end{array}$ & Pleistocene age & $\begin{array}{l}\text { Gaj formation, } \\
\text { Miliolitic variety }\end{array}$ \\
\hline 2. & Junagarh & $\begin{array}{l}\text { Adityana, Bakhrala, Bharvada, Bokira, Bolas, } \\
\text { Boricha, Degam, Gosa, Ishwariya, Kajawardi, } \\
\text { Kentela, Kharsa, Khera,Lati, Maraj, Palakhad, } \\
\text { Pandavar, Parachi, Rakhej, Rampura, Ranavav, } \\
\text { Samadhiala, Saroswa , Shantipura, simar, Su- } \\
\text { pasi, sutrapra, Umba, Vavdi and Veraval. }\end{array}$ & $\begin{array}{c}\text { Pliocene age } \\
\text { and } \\
\text { Pleistocene age }\end{array}$ & $\begin{array}{l}\text { Dwarka formations } \\
\text { and } \\
\text { Chaya formations }\end{array}$ \\
\hline $3 .$. & Kuchch & $\begin{array}{l}\text { Ramania, Waghapadar, sanosra, Khari, Fulra, } \\
\text { Kuriyani. Lakhpat, ratipur, Kharoda and Harudi }\end{array}$ & Eocene/Miocene age & Nummulitic Variety \\
\hline 4. & Bhavnagar & Gopnath, Mahuva, Methala, Talaja & Pleistocene age & Miliolitic variety \\
\hline 5. & Bharuch & $\begin{array}{l}\text { Konda (Ankleshwar), Dungri, Ghoda ,Valia } \\
\text { etc.) }\end{array}$ & Eocene/Miocene age & Nummulitic Variety \\
\hline \multirow[t]{2}{*}{6.} & \multirow[t]{2}{*}{ Jamnagar } & $\begin{array}{l}\text { Mithapur, Ranpur, Sikka, Dhrasanvel, Kalyan- } \\
\text { pur, Lalpur and Kuranga etc. }\end{array}$ & Pliocene age & $\begin{array}{c}\text { Arenaceous limestone / } \\
\text { Dwarka formations and } \\
\text { miliolitic variety. }\end{array}$ \\
\hline & & $\begin{array}{l}\text { Gorinja, Bhimpura,Meripur and Ashapura Mata } \\
\text { Temple. }\end{array}$ & Pleistocene age & Gaj formations \\
\hline
\end{tabular}

Source: [4]

\section{Hydro-geology}

All the sites are situated close to the coast (with in distance of 1-2 km). In Site 1, the topography is generally flat to undulating. There are limestone cliffs along the sea coast near Jaffrabad and Babarkot villages. The Deccan Trap basalt of cretaceous to Eocene age is oldest rock formation in the study area. It is overlain by the Tertiary Gaj Bed which in turn is overlain by milliolitic limestone of Miocene-Pliocene age. The milliolitic limestone is the 
major water bearing formation in Sites 1 and 2.

Alluvial formation also forms a minor aquifer system in patches in the Site 2. The pumping test carried out at Site 2 estimates the transmissivity as $62.26 \mathrm{~m}^{2} /$ day and permeability as $15.11 \mathrm{~m} /$ day. The water level varies from $2.50 \mathrm{~m}$ to $30.35 \mathrm{~m}(\mathrm{bgl})$ during the pre-monsoon period and $0.35 \mathrm{~m}$ to $24.40 \mathrm{~m}$ (bgl) during post-monsoon period. All the wells are fitted with pumps having prime movers of less than $7.5 \mathrm{HP}$ which sustain pumping of 2 to 8 $\mathrm{hrs} /$ day with a discharge of 100 to 350 LPM.

In Site 3, the area is occupied by $0.5 \mathrm{~m}$ to $3.0 \mathrm{~m}$ of alluvium followed by Gaj limestone which acts as aquifer in major part of the south east area. In the eastern part of the site, the milliolitic limestone acts as the main aquifer. The aquifer is both unconfined (top) and semi-confined in nature. The unconfined aquifer lies between depth range of 1 to $22.5 \mathrm{~m}$ and the semi-confined aquifer lies between depths of $22.5 \mathrm{~m}$ to $50.0 \mathrm{~m}$ [2].

There is no industrial use of groundwater by the mining companies at the three sites. However, water is used for agriculture extensively. All the three sites receive moderate rainfall and it varies from $600 \mathrm{~mm}$ to $800 \mathrm{~mm}$ on average.

\section{Methodology}

The R\&D analysis presented in this paper makes use of the water quality data collected by different national agencies and local organization namely Central Mining Research Institute (CMRI), National Environmental Engineering Research Institute (NEERI) and Gujarat Water Resources Development Corporation Limited (GWRDC), Govt. of Gujarat and Ground Water \& Mineral Investigation Consultancy Limited (GWMICL) [1-3] during the period 2002-2007. The approach is to consolidate a large volume of available primary and secondary data and derive useful conclusions on groundwater quality vis-à-vis the sea water intrusion. The range and average values of the hydro-chemical data for the three sites are presented in Tables 2-4.

The well established concept of 'watershed' (for Site 1) and 'core area/buffer area zoning' (for Site 2 and Site 3) has been adopted for the data collection and collation of the study area. An observation well network consisting of representative wells was set up for monitoring of water level and water quality. Samples were collected in pre-cleaned poly-propylene bottles and analyzed for major cations and anions as per the standard procedure of American Public Health Association [5].

\section{Discussions and Analysis}

Evidences of sea water intrusion in different parts of the

Table 2. Qualitative analysis of ground water at site 1-Kovaya.

\begin{tabular}{|c|c|c|c|c|c|c|}
\hline \multirow{3}{*}{ S. No. } & \multirow{3}{*}{ Parameter $\boldsymbol{\nabla}$} & \multirow{3}{*}{ Unit $\nabla$} & \multicolumn{4}{|c|}{2006} \\
\hline & & & \multicolumn{2}{|c|}{ a) Range } & \multicolumn{2}{|c|}{ b) Average } \\
\hline & & & Pre Monsoon & Post Monsoon & Pre Monsoon & Post Monsoon \\
\hline 1. & $\mathrm{pH}$ & - & $7.3-8.1$ & $7.1-7.9$ & 7.6 & 7.45 \\
\hline 2. & Elect. Conductivity & $\underset{\mathrm{m}}{\mu \mathrm{mhos} / \mathrm{c}}$ & $750-12300$ & $1112-13160$ & 4820.55 & 4433.37 \\
\hline 3. & TDS & $\mathrm{mg} / \mathrm{L}$ & $450-7380$ & $667.2-7896$ & 2892 & 2660 \\
\hline 4. & Total Hardness & $\mathrm{mg} / \mathrm{L}$ & $120-669$ & $132-800$ & 384.33 & 348.25 \\
\hline 5. & Total Alkalinity & $\mathrm{mg} / \mathrm{L}$ & $122-498$ & $176-496$ & 318.77 & 315.25 \\
\hline 6. & Calcium (Ca) & $\mathrm{mg} / \mathrm{L}$ & $88-516$ & $78-470$ & 236.83 & 171.87 \\
\hline 7. & Magnesium (Mg) & $\mathrm{mg} / \mathrm{L}$ & $28-280$ & $38-470$ & 147.5 & 179 \\
\hline 8. & Sodium (Na) & $\mathrm{mg} / \mathrm{L}$ & $97-2650$ & $185-2550$ & 992.83 & 840.06 \\
\hline 9. & Potassium (K) & $\mathrm{mg} / \mathrm{L}$ & $2.0-80.0$ & $10-99.5$ & 26.38 & 89.375 \\
\hline 10. & $\mathrm{HCO}_{3}$ & $\mathrm{mg} / \mathrm{L}$ & $148.84-601.56$ & $215-605$ & 388.90 & 384.68 \\
\hline 11. & Chlorides (as Cl) & $\mathrm{mg} / \mathrm{L}$ & 103-3899 & $200-3500$ & 1401.72 & 1280.50 \\
\hline 12. & Sulphates $\left(\right.$ as $\left.\mathrm{So}_{4}\right)$ & $\mathrm{mg} / \mathrm{L}$ & $10-199$ & $16-219$ & 75.27 & 88.68 \\
\hline
\end{tabular}

Note: ND = not detected; Period-April, 2006 \& Sept, 2006; nineteen sampling locations: Source: [1]. 
Table 3. Qualitative analysis of ground water at site 2-NCCL.

\begin{tabular}{|c|c|c|c|c|c|c|}
\hline \multirow{3}{*}{$\begin{array}{l}\text { S. } \\
\text { No. }\end{array}$} & \multirow{3}{*}{ Parameter $\nabla$} & \multirow{3}{*}{ Unit $\nabla$} & \multicolumn{4}{|c|}{ Year 2004} \\
\hline & & & \multicolumn{2}{|c|}{ a) Range } & \multicolumn{2}{|c|}{ b) Average } \\
\hline & & & $\begin{array}{c}\text { Pre } \\
\text { Monsoon }\end{array}$ & $\begin{array}{c}\text { Post } \\
\text { Monsoon }\end{array}$ & $\begin{array}{c}\text { Pre } \\
\text { Monsoon }\end{array}$ & $\begin{array}{c}\text { Post } \\
\text { Monsoon }\end{array}$ \\
\hline 1. & $\mathrm{pH}$ & - & $7.24-7.85$ & $7.03-8.1$ & 7.52 & 7.57 \\
\hline 2. & Elect. Conductivity & $\underset{\mathrm{m}}{\mu \mathrm{mhos} / \mathrm{c}}$ & $875-5803$ & $942.5-7034.3$ & 2737.45 & 2784.13 \\
\hline 3. & TDS & $\mathrm{mg} / \mathrm{L}$ & $560-3281.43$ & $686.66-4040$ & 1735.74 & 1760.34 \\
\hline 4. & Total Hardness & $\mathrm{mg} / \mathrm{L}$ & $102.8-606.5$ & $83.66-728.71$ & 258.89 & 228.10 \\
\hline 5. & Total Alkalinity & $\mathrm{mg} / \mathrm{L}$ & $0-20$ & $0-10$ & 8.44 & 3.13 \\
\hline 6. & Calcium $(\mathrm{Ca})$ & $\mathrm{mg} / \mathrm{L}$ & $41-242.5$ & $33.33-291.42$ & 103.44 & 84.44 \\
\hline 7. & Magnesium (Mg) & $\mathrm{mg} / \mathrm{L}$ & $27-171$ & $39.0-264.0$ & 79.064 & 91.49 \\
\hline 8. & Sodium $(\mathrm{Na})$ & $\mathrm{mg} / \mathrm{L}$ & $58.5-767.57$ & $83-908.66$ & 387.70 & 391.71 \\
\hline 9. & Potassium (K) & $\mathrm{mg} / \mathrm{L}$ & $0.25-13.9$ & $0.125-25.92$ & 2.62 & 4.76 \\
\hline 10. & $\mathrm{HCO}_{3}$ & $\mathrm{mg} / \mathrm{L}$ & $183-646.66$ & $262-614$ & 342.69 & 417.5 \\
\hline 11. & Chlorides (as Cl) & $\mathrm{mg} / \mathrm{L}$ & $84-1823.0$ & $128-2194.3$ & 728.02 & 692.55 \\
\hline 12. & Sulphates (as $\left.\mathrm{SO}_{4}\right)$ & $\mathrm{mg} / \mathrm{L}$ & $0-157.25$ & 29.33 & 72.30 & 140.44 \\
\hline
\end{tabular}

Note: Pre-monsoon and Post-monsoon data are collected from 23 locations (104 sampling points) located in Jafrabad and Rajula taluka. (a) Pre monsoon Period = April-May, 2004 and Post monsoon Period = Sept-October, 2004.

Source: [3]

Table 4. Qualitative analysis of ground water at site 3-Lodhwa/Singsar.

\begin{tabular}{|c|c|c|c|c|c|}
\hline $\begin{array}{l}\text { S. } \\
\text { No. }\end{array}$ & Parameter $\boldsymbol{\nabla}$ & Unit $\boldsymbol{\nabla}$ & $\begin{array}{c}\text { Range } \\
(2002-2003)\end{array}$ & $\begin{array}{c}\text { Average } \\
(2002-2003)\end{array}$ & Remarks \\
\hline 1. & $\mathrm{pH}$ & - & $6.74-7.6$ & 7.015 & \multirow{13}{*}{$\begin{array}{l}\text { Based on seven sampling points; } \\
\text { Period of sampling-November } \\
2002 \text { to April } 2003 \text {. } \\
\text { Separate data for pre-monsoon } \\
\text { and post-monsoon are not } \\
\text { available. }\end{array}$} \\
\hline 2. & Elect. Conductivity & $\mu \mathrm{mhos} / \mathrm{cm}$ & 4353.3-35016.66 & 7407 & \\
\hline 3. & TDS & $\mathrm{mg} / \mathrm{L}$ & $2612-21010$ & 8364 & \\
\hline 4. & Total Hardness & $\mathrm{mg} / \mathrm{L}$ & $850-4603$ & 3199 & \\
\hline 5. & Total Alkalinity & $\mathrm{mg} / \mathrm{L}$ & $220-368$ & 310.5 & \\
\hline 6. & Calcium (Ca) & $\mathrm{mg} / \mathrm{L}$ & $410-1908$ & 938 & \\
\hline 7. & Magnesium (Mg) & $\mathrm{mg} / \mathrm{L}$ & $149.57-514.0$ & 377.25 & \\
\hline 8. & Sodium $(\mathrm{Na})$ & $\mathrm{mg} / \mathrm{L}$ & $248.0-649.0$ & 496 & \\
\hline 9. & Potassium (K) & $\mathrm{mg} / \mathrm{L}$ & $16.22-63.65$ & 32.34 & \\
\hline 10. & $\mathrm{HCO}_{3}$ & $\mathrm{mg} / \mathrm{L}$ & $268.4-448.96$ & 378.81 & \\
\hline 11. & Chlorides (as $\mathrm{Cl}$ ) & $\mathrm{mg} / \mathrm{L}$ & $435-5546.0$ & 3682.5 & \\
\hline 12. & Sulphates (as $\mathrm{SO}_{4}$ ) & $\mathrm{mg} / \mathrm{L}$ & $310.17-1510.0$ & 598.5 & \\
\hline 13. & Total Suspended Solids (TSS) & $\mathrm{mg} / \mathrm{L}$ & $20-260$ & 112.5 & \\
\hline
\end{tabular}

Source: [2] 
world have been reported through hydro-chemical studies [6-16]. The present study seeks to investigate the possible signature of sea water intrusion in the coast aquifer at three different sites on the basis of hydro-chemistry. The $\mathrm{Cl} / \mathrm{HCO}_{3}$ ratio has been computed for different samples to infer about the possible signatures of sea water intrusion [11].

On the basis of hydro-chemistry of groundwater following important points have been analyzed which are discussed below:

1) The ground water quality at all sites indicates higher concentration of TDS, chloride and sodium (Table 2-4). At most of the places TDS is higher than $1000 \mathrm{mg} / \mathrm{L}$ value. The average EC in 2006 at Kovaya (Table 2) for pre-monsoon and post-monsoon happen to be $4820 \mathrm{mg} / \mathrm{L}$ and $4423 \mathrm{mg} / \mathrm{L}$ respectively and thereby indicate the saline character of the aquifer as per the classification by Saxena et al. [10]. It is observed that nearly $50 \%$ of the samples exceed the desirable limits $(2000 \mathrm{mg} / \mathrm{L})$ of TDS set by the BIS 1991. It is also evi-

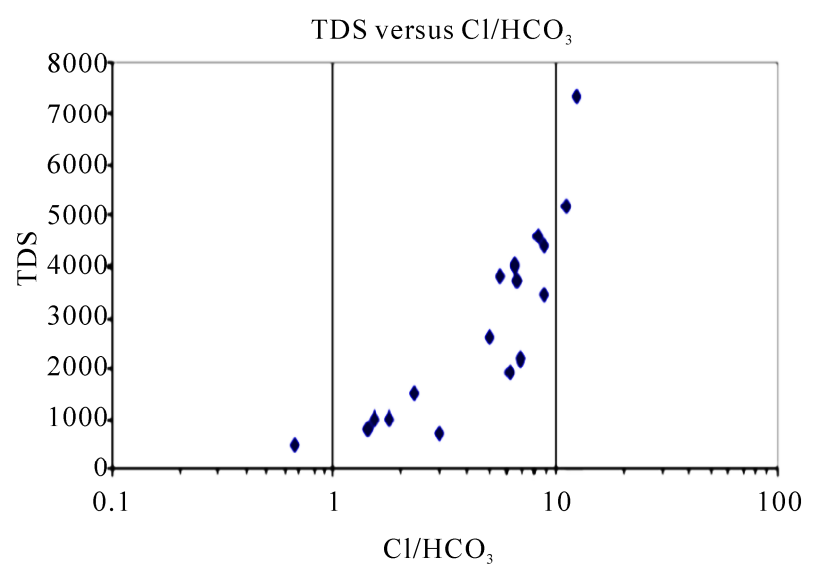

(a)

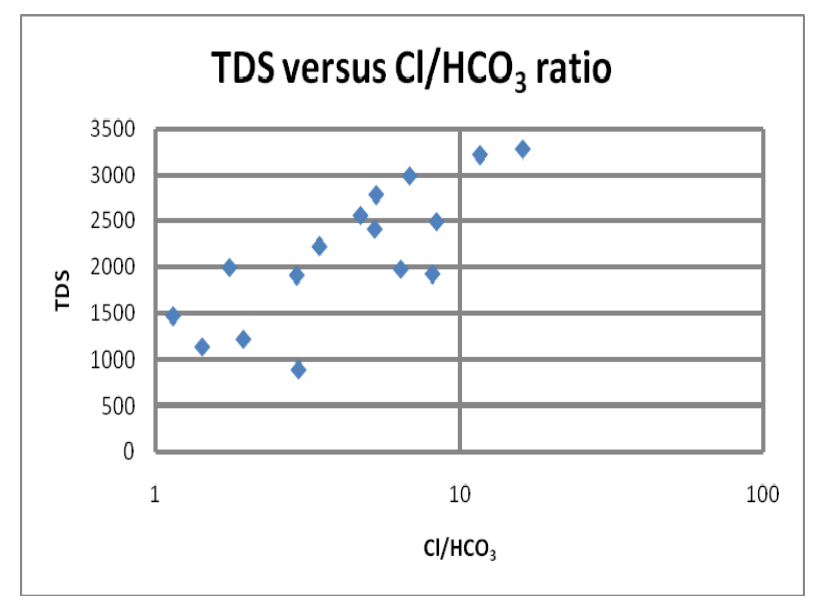

(c) dent for the sites at NCCL (Table 3) and GACL (Table 4) that the groundwater is brackish type (average EC > $1500 \mu \mathrm{S} / \mathrm{cm})$.

2) The TDS versus $\mathrm{Cl} / \mathrm{HCO}_{3}$ for different samples has been computed for the three study areas. Since, $\mathrm{Cl} / \mathrm{HCO}_{3}$ is greater than 1 for most of the samples, it is indicative of sea water intrusion [11] in the study area (Figures 2(a)-(d)).

3) Samples have been collected from the Arabian sea and analyzed for physico-chemical parameters (Table 5). It is observed that $\mathrm{pH}$ is over 7 and seawater has very high TDS in the range of 44,545-65,866 mg/L. The high concentration of $\mathrm{Ca}, \mathrm{Mg}, \mathrm{Na}$ and $\mathrm{K}$ makes the seawater harder $(7666 \mathrm{mg} / \mathrm{L}$ to $10,055 \mathrm{mg} / \mathrm{L})$ and alkaline (Total Alkalinity range $=120-210 \mathrm{mg} / \mathrm{L})$. Similarly, chloride $(24,880-38,333 \mathrm{mg} / \mathrm{L})$, sulphates (1366-4669.5 mg/L) and $\mathrm{HCO}_{3}$ content $(146.4-220 \mathrm{mg} / \mathrm{L})$ of seawater is also observed. The coastal aquifer has good transmissivity and permeability (Table 6).

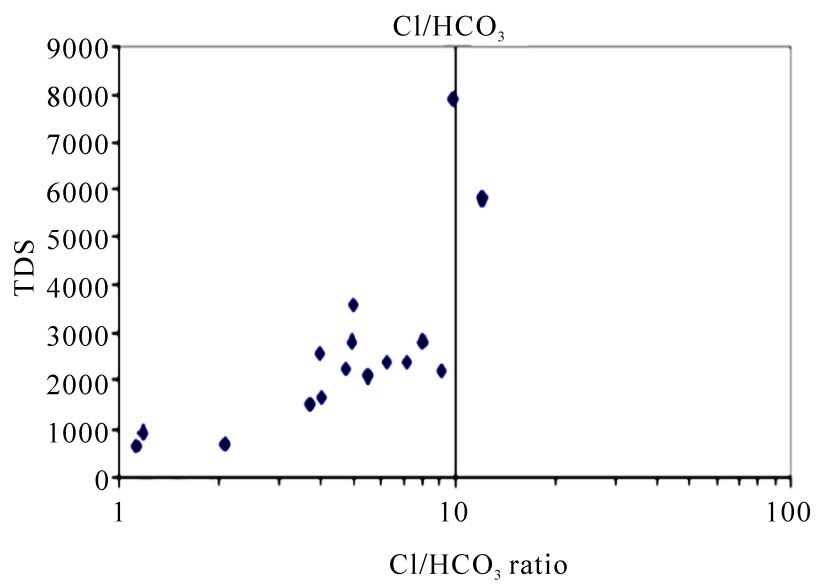

(b)

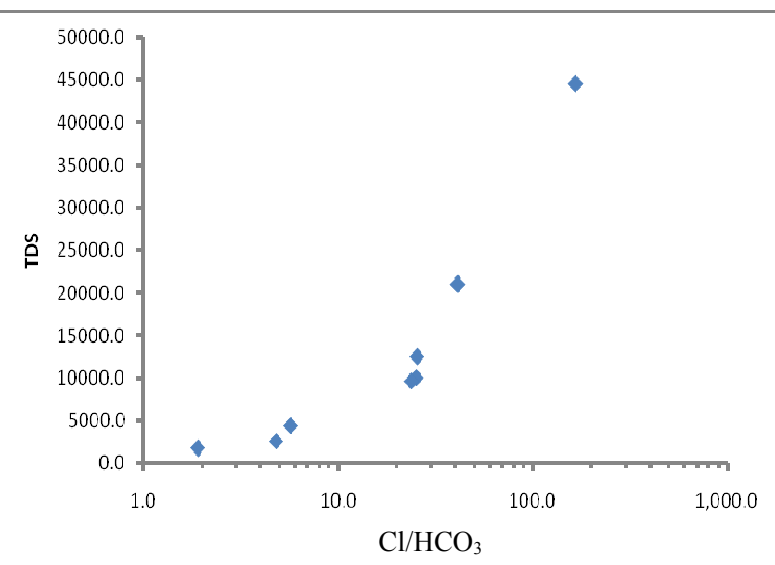

(d)

Figure 2. Cross plots of TDS vs $\mathrm{Cl} / \mathrm{HCO}_{3}$ ratio. ((a) \& (b) ) for Kovaya; (c) for NCCL and (d) for GACL Sites. 
Table 5. Arabian seawater quality in gujarat coast, India.

\begin{tabular}{|c|c|c|c|c|c|c|c|c|c|c|c|c|c|c|c|c|c|}
\hline $\begin{array}{l}\text { S. } \\
\text { No. }\end{array}$ & $\begin{array}{l}\text { Sampling Station } \\
\text { (Location) }\end{array}$ & $\mathrm{pH}$ & $\begin{array}{l}\text { Cond. } \\
(\mathrm{mS} / \mathrm{cm})\end{array}$ & $\begin{array}{c}\text { TDS } \\
(\mathrm{mg} / \mathrm{L})\end{array}$ & $\begin{array}{l}\text { Turb } \\
\text { (NTU) }\end{array}$ & $\begin{array}{l}\text { T.Alk } \\
(\mathrm{mg} / \mathrm{L})\end{array}$ & $\begin{array}{l}\text { T-Hard } \\
(\mathrm{mg} / \mathrm{L})\end{array}$ & $\begin{array}{c}\mathrm{Ca} \\
(\mathrm{mg} / \mathrm{L})\end{array}$ & $\begin{array}{c}\mathrm{Mg} \\
(\mathrm{mg} / \mathrm{L})\end{array}$ & $\begin{array}{c}\mathrm{SO}_{4} \\
(\mathrm{mg} / \mathrm{L})\end{array}$ & $\begin{array}{c}\mathrm{Cl} \\
(\mathrm{mg} / \mathrm{L})\end{array}$ & $\begin{array}{c}\mathrm{NO}_{3} \\
(\mathrm{mg} / \mathrm{L})\end{array}$ & $\begin{array}{c}\mathrm{PO}_{4} \\
(\mathrm{mg} / \mathrm{L})\end{array}$ & $\underset{(\mathrm{mg} / \mathrm{L})}{\mathrm{Na}}$ & $\underset{(\mathrm{mg} / \mathrm{L})}{\mathrm{K}}$ & $\mathrm{CO}_{3}$ & $\mathrm{HCO}_{3}$ \\
\hline 1 & $\begin{array}{c}\text { Location } 1 \\
\text { (Varahswarup) }\end{array}$ & 8.0 & 107241 & 64345 & 5.00 & 120 & 7566 & 1080 & 6486 & 1366 & 38333 & 149 & 1.0 & 21299 & 1100 & 72 & 146.4 \\
\hline 2. & $\begin{array}{c}\text { Location2 } \\
\text { (Varahswarup) }\end{array}$ & 7.6 & 109777 & 65866 & 6.20 & 180 & 8400 & 4080 & 4321 & 1452 & 37000 & 149 & 2.2 & 23095 & 1362 & 108 & 220 \\
\hline 3. & $\begin{array}{l}\text { Location } 3 \\
\text { (Dhamlage) }\end{array}$ & 8.33 & 71,272 & 44545 & $>10$ & 210 & 10,055 & 2245 & 1080 & 4669.55 & 24880 & 1658 & - & 22.25 & 337.22 & - & - \\
\hline
\end{tabular}

Note: Varahswarup and Dhamlage are located in Amreli District and Junagarh district respectively. The water sampling and analysis months for location 1, $2 \& 3$ are April, 2006; September, 2006 and 2005 respectively.

Table 6. Aquifer parameters at studied locations.

\begin{tabular}{|c|c|c|c|c|c|c|}
\hline S. No. & Parameter & Unit & $\begin{array}{c}\text { Site } 1 \\
\text { (Kovaya) }\end{array}$ & $\begin{array}{c}\text { Site } 2 \\
(\mathrm{NCCL})\end{array}$ & Site 3 (Lodhwa/Singsar) & Remarks \\
\hline 1. & Transmissivity & $\mathrm{M}^{2} /$ day & 62.26 & 62.26 & $58.82-78.15$ & \multirow{4}{*}{$\begin{array}{l}\text { Site } 1 \text { and Site } 2 \text { are } \\
\text { in close vicinity to } \\
\text { each other and } \\
\text { hence almost same } \\
\text { values of aquifer } \\
\text { parameters. }\end{array}$} \\
\hline 2. & Permeability & $\mathrm{M} /$ day & 15.11 & 15.11 & - & \\
\hline 3. & Specific Capacity & $\mathrm{M}^{3} / \mathrm{min} / \mathrm{m}$ & 0.080 & 0.080 & - & \\
\hline 4. & Specific Yield & Fraction/ratio & 0.031 & 0.031 & $0.20-0.26$ & \\
\hline
\end{tabular}

High TDS values exceeding $1000 \mathrm{mg} / \mathrm{L}$ (Table 7) and misbalance of Anion and Cation ratio [12] is yet another commonly observed characteristics in coastal aquifer. Both of these conditions are observed in limestone tract also as evident from the qualitative analysis of ground water at the studied sites.

Thus, geological factors (the principal rock type), aquifer present (limestone and host rocks) and hydrological conditions [porosity: 0-20\% (primary \& secondary both), and transmissivity of aquifer $\left(58.82-78.15 \mathrm{~m}^{2} /\right.$ day)] permit the solute transport process underground, which ultimately leads to the presence of sea water influx at different studied sites. Using sustainable ground water management techniques, the interface can be kept contained towards sea coast.

\section{Sustainable Use of Groundwater}

In the light of the data analysis the following recommendations are made.

Table 7. Ground water classification based on TDS.

\begin{tabular}{ccc}
\hline S. No. & Category & Total Dissolved solids $(\mathbf{m g} / \mathbf{L})$ \\
\hline 1. & Fresh water & $0-1000$ \\
2. & Brackish water & $1000-10,000$ \\
3. & Saline water & $10,000-100,000$ \\
4. & Brine water & $>100,000$ \\
\hline
\end{tabular}

1) Recharge of the coastal aquifer is one of the viable strategies to reduce the salinity of the aquifer and render it potable.

2) The recharging partially compensates the ground water exploitation and also ensures the availability of ground water $[9,15,16]$. The abandoned pits in mining areas and low lying land areas can be used for artificial recharge.

3) The industries operating in the studied limestone tract should install "desalination plants" for their domestic as well as industrial requirements [13].

4) Over-exploitation of the groundwater through installation of private boring wells needs to be strongly discouraged. Drip irrigation should be encouraged tominimize the use of groundwater.

5) Technique of "water barriers" as done in different countries [14] in such areas should be encouraged.

\section{Conclusions}

1) The hydro-chemical data from the groundwater samples i.e. higher TDS values and $\mathrm{Cl} / \mathrm{HCO}_{3}>1$ indicate that the studied Saurashtra coastal aquifer has been subjected to sea water intrusion.

2) Based on the field survey and data analysis, it is inferred that the intrusion is possibly triggered by the presence of large number of agricultural wells (excessive extraction of groundwater) in the study area. It is also observed that recharge from precipitation or other sources is not proportionate and this has not compensated the replenishment of groundwater in the study area. 
3) Though there is less use of the groundwater by the industrial organization (cement companies) for their industrial requirement, the coastal aquifer is excessively exploited for agricultural use. The pumpage of water from the coastal aquifer seems to be responsible for reversal of the hydraulic gradient and inducing sea water intrusion in the mainland area.

4) Hydro-geological factors permit the solute transport process leading to the presence of sea water influx at different studied sites. The coastal aquifer of Saurashtra Coast has good permeability and transmissivity and records higher specific conductance of ground because of high salinity/alkalinity.

5) Using sustainable ground water management techniques the interface can be kept contained towards sea coast.

\section{Acknowledgements}

Authors want to thanks the management of GCW, NCCL and GACL for fruitful interaction and technical discussions. The encouragement provided by Director, CIMFR and Director, NEERI is thankfully acknowledged.

\section{References}

[1] Central Mining Research Institute, "Geo-hydrological Studies for Kovaya Limestone Mine of Ultratech Cement Company Limited," 2007, p. 1-103.

[2] Gujarat Ambuja Cement Limited, "Regional Ground Water Status of Buffer Zone, Remote Sensing Studies and the Detailed Ground Water Assessment, Dewatering Plan, 3D Computer Simulation, Mathematical Modelling and Water Management in the Lodhwa Core Zone: A Technical Report of Gujarat Ambuja Cement Limited," Ground Water \& Mineral Investigation Consultancy Centre Limited, Jaipur, 2004, p. 1-214.

[3] Gujarat Water Resources Development Corporation Limited, "A Report on Ground Water Investigation and Ground Water Potential Details Around Narmada Cement factory," Gandhinagar, 2005, p. 1-30.

[4] Geological Survey of India, "Geology and Mineral resources of Gujarat Daman and Diu," Geological Survey of India (GSI) Miscellaneous Publication, No. 30, 2001, p.
$1-102$.

[5] American Public Health Association "Standard Methods for Analysis of Water and Waste Water," 20th Edition, 1998.

[6] P. R. Pujari and A. K. Soni, "Sea Water Intrusion Studies near Kovaya Limestone Mine, Saurashtra Coast, India," Environmental Monitoring and Assessment, Vol. 154, No. 1-4, July 2009, pp. 93-109.

[7] P. Pulido-Laboeuf, "Sea water intrusion and Associated Processes in a Small Complex Aquifer (Castel de Ferro, Spain)," Journal of Applied Geochemistry, Vol. 19, No. 10, October 2004, pp. 1517-1527.

[8] M. Abdulaziz, M. Al-Bassam and Tahir Hussein, "Combined Geo-electrical and Hydro-chemical Methods to Detect Salt-Water Intrusion: A Case Study from Southwest Saudi Arabia," Management of Environmental Quality, Vol. 19, No. 2, 2008, pp. 179-193.

[9] B. F. Jones, A. Vengosh, E. Roshenthal and Y. Yechelli, "Geo-chemical Investigations: Seawater Intrusion in Coastal Aquifer Concepts, Methods and Practices," In: J. Bear, Ed., Kluwer Academic Publishers, Dordrecht, 1999.

[10] V. K. Saxena, N. C. Mondal and V. S. Singh, "Evaluation of Hydro-geochemical Parameters to Delineate Fresh Groundwater Zones in Coastal Aquifers," Journal of Applied Geochemistry, Vol. 6, 2004, pp. 245-254.

[11] R. Revelle, "Criteria for Recognizing Sea Water in Groundwater," Transactions on American Geophysical Union, Vol. 22, 1941, pp. 593-597.

[12] R. K. Trivedy and P. K. Goel, "Chemical and Biological Methods for Water Pollution Studies," Environmental Publications, Karad, 1984, pp. 1-22.

[13] D. Kharkar, "Desalination Plant of GCW," Official Communication, 2006, Unpublished.

[14] H. R. Henry, "Salt Intrusion into Coastal Aquifer," International Association of Hydrological Sciences Publication. Vol. 52, 1960, pp. 478-487.

[15] A. A. M. Ebrahim, M. M. Senosy and K. A. Dahab, "Geoelectrical and Hydro-chemical Studies for Delineating Groundwater Contamination due to Saltwater Intrusion in the Northern Part of the Nile Delta, Egypt," Groundwater, Vol. 35, No. 2, 1997, pp. 216-222.

[16] U. Hamzah, A. R. Samsudin and E. P. Malim, "Groundwater Investigation in Kuala Selangor Using Vertical Electrical Sounding (VES) Surveys," Environmental Geology, Vol. 51, No. 8, February 2007, pp. 1349-1359. 